\title{
МЕДИЦИНСКОЕ ПРАВО
}

\author{
DOI: 10.17803/1994-1471.2020.114.5.160-167
}

Н. С. Посулихина*

\section{Лицензионный режим обращения биомедицинских клеточных продуктов: проблемы правоприменения}

Аннотация. Статья посвящена рассмотрению вопросов, связанных с правовым регулированием в сфере биологической безопасности. В ходе исследования выделены особенности лицензионного режима производства и обращения биомедицинских клеточных продуктов как в России, так и за рубежом, проведен дифференцированный анализ понятий «правовой режим» и «лицензионный режим» оборота биомедицинских клеточных продуктов, изучены организационно-правовые особенности общего и специального лицензионных режимов обращения биомедицинских клеточных продуктов, определены приоритетные направления законотворческой деятельности в части обеспечения функционирования специального лицензионного режима обращения биомедицинских клеточных продуктов. Установлено, что в отечественном законодательстве отсутствует дефиниция лицензионного режима в целом и лицензионного режима производства и обращения биомедицинских клеточных продуктов в частности, не закреплены особенности специального лицензионного режима обращения биомедицинских клеточных продуктов. Сделан вывод о том, что формирование нормативно-правовой основы лицензионного режима производства и обращения биомедицинских клеточных продуктов является одним из ведущих направлений обеспечения биологической безопасности как в России, так и за рубежом. Отсутствие нормативно закрепленного комплекса профилактических мероприятий, направленных на минимизацию рисков распространения инфекционных заболеваний в результате применения биомедицинских клеточных продуктов, способно нанести существенный вред биологической безопасности государства.

Ключевые слова: лицензионный режим; биологическая безопасность; государственное регулирование; защищенность; профилактические мероприятия; право; законодательство; биомедицинские клеточные продукты; международный медицинский кластер; Сколково; лицензионный контроль.

Для цитирования: Посулихина Н. С. Лицензионный режим обращения биомедицинских клеточных продуктов: проблемы правоприменения // Актуальные проблемы российского права. - 2020. - Т. 15. - № 5. C. 160-167. — DOI: 10.17803/1994-1471.2020.114.5.160-167.

(C) Посулихина Н. С., 2020

* Посулихина Наталья Семеновна, кандидат юридических наук, преподаватель кафедры медицинского права Московского государственного юридического университета имени О.Е. Кутафина (МГЮА) Садовая-Кудринская ул., д. 9, г. Москва, Россия, 125993

nsposulihina@msal.ru 


\title{
Licensed Biomedical Cellular Products Circulation: Enforcement Issues
}

\author{
Natalya S. Posulikhina, Cand. Sci. (Law), Lecturer of the Department of Medical Law, Kutafin \\ Moscow State Law University (MSAL) \\ ul. Sadovaya-Kudrinskaya, d. 9, Moscow, Russia, 125993 \\ nsposulihina@msal.ru
}

\begin{abstract}
The paper is devoted to the consideration of issues related to legal regulation in the field of biological safety. The study highlights the features of the licensed regime for the production and circulation of biomedical cell products both in Russia and abroad. The author conducts a differentiated analysis of the concepts of "legal regime" and "licensed regime" of the turnover of biomedical cell products, studies the organizational and legal features of the general and special licensed regimes circulation of biomedical cell products. The paper identifies priority areas of legislative activity in terms of ensuring the functioning of special licensed treatment regime for biomedical cell products. It is established that in the domestic legislation there is no definition of the licensed regime in general and the licensed regime for the production and circulation of biomedical cell products in particular, the features of the special licensed regime for the circulation of biomedical cell products have not been fixed. The author concludes that the formation of the regulatory framework of the licensed regime for the production and circulation of biomedical cell products is one of the leading directions in ensuring biological safety both in Russia and abroad. The absence of a normatively fixed set of preventive measures aimed at minimizing the risks of the spread of infectious diseases because of the use of biomedical cell products can significantly harm the biological safety of the state.
\end{abstract}

Keywords: licensed regime; biosafety; state regulation; security; preventive actions; right; legislation; biomedical cell products; international medical cluster; Skolkovo; licensing control.

Cite as: Posulikhina NS. Litsenzionnyy rezhim obrashcheniya biomeditsinskikh kletochnykh produktov: problemy pravoprimeneniya [Licensed Biomedical Cellular Products Circulation: Enforcement Issues]. Aktualnye problemy rossiyskogo prava. 2020;15(5):160-167. DOI: 10.17803/1994-1471.2020.114.5.160-167. (In Russ., abstract in Eng.).

A ктивный интерес к проблемам защищенности государства и общества от биологических угроз в настоящее время обусловлен, в частности, рядом последовательных событий общемирового масштаба ${ }^{1}$ и планомерным внедрением в общемировую практику результатов научно-технического прогресса, особенно в сфере оборота биомедицинских технологий. С правовой точки зрения особый интерес в сфере государственного регулирования вопросов биобезопасности представляют особенности лицензионного режима производства и обращения биомедицинских клеточных продуктов как в России, так и за рубежом.
В первую очередь следует отметить, что в отечественном законодательстве отсутствует дефиниция лицензионного режима в целом и лицензионного режима производства и обращения биомедицинских клеточных продуктов в частности. Следовательно, обратимся к отраслевой доктрине для уточнения термина.

В современной доктрине применительно к экономической деятельности выделяются общий, специальные и особые правовые режимы². Так, А. А. Мохов отмечает, что ряд особенностей биомедицинских клеточных продуктов как объектов гражданских прав предопределяет закрепление специального правового режима их оборота³.

1 Alder Hey doctor cleared of misconduct // URL: http://news.bbc.co.uk/2/hi/uk_news/england/2504703.stm ; No charge for Alder Hey organs pathologist // URL: https://www.dailymail.co.uk/news/article-330939/Nocharge-Alder-Hey-organs-pathologist.html.

2 Правовое регулирование экономической деятельности: единство и дифференциация / отв. ред. И. В. Ершова, А. А. Мохов. М. : Норма: Инфра-М, 2017. С. 115-125.

3 Мохов А. А. Правовой режим биомедицинских клеточных продуктов как объектов гражданских прав // Гражданское право. 2017. № 3. С. 29-31. 
Рассматривая правовую сущность лицензионного режима оборота биомедицинских клеточных продуктов, целесообразно отметить, что следует разграничивать такие понятия, как «правовой режим» и «лицензионный режим оборота биомедицинских клеточных продуктов». Категория «правовой режим» носит более общий, собирательный характер по отношению к вопросам правового обеспечения существования такого объекта экономического оборота, как биомедицинские клеточные продукты. Рассматривая же лицензионный режим производства и обращения биомедицинских клеточных продуктов, целесообразно отметить, что данная категория носит узконаправленный характер, определяющий особенности государственного регулирования сферы производства и обращения, а также контроля качества биомедицинских клеточных продуктов. Таким образом, в рамках специального правового режима оборота биомедицинских клеточных продуктов возможно сосуществование двух лицензионных режимов обращения биомедицинских клеточных продуктов:

1) общего лицензионного режима;

2) специального лицензионного режима.

К характерным особенностям общего лицензионного режима относятся базовые лицензионные требования, предъявляемые к соискателю лицензии (лицензиату) при осуществлении им деятельности по производству биомедицинских клеточных продуктов, определенные в постановлении Правительства РФ от 03.10.2018 № 11844: наличие соответствующих помещений и оборудования; соблюдение правил надлежащей практики по работе с биомедицинскими клеточными продуктами тов производства биомедицинских клеточных продуктов, наличие аттестованного уполномоченного лица производителя биомедицинских клеточных продуктов и др.
Если характерные особенности общего лицензионного режима производства и обращения биомедицинских клеточных продуктов законодателем относительно определены (хотя существует множество пробелов и неточностей), то особенности производства и обращения биомедицинских клеточных продуктов в рамках специального лицензионного режима полностью выпадают из внимания законодателя и требуют дополнительных разъяснений, в частности: 1) специальный правовой статус субъекта экономической деятельности, участвующего в производстве и обороте биомедицинских клеточных продуктов, в том числе особенности статуса иностранных агентов в рассматриваемой сфере;

2) территория, на которую распространяется действие специального лицензионного режима (например, территория ИЦ «Сколково», территория международного медицинского кластера, территория опережающего социально-экономического развития и т.д.);

3) длительность существования преференций по упрощенной процедуре производства и обращения биомедицинских клеточных продуктов на отдельных территориях (срочный характер или бессрочный) и ряд других правовых вопросов.

Отдельно следует отметить, что понятие лицензионного режима обращения биомедицинских клеточных продуктов может рассматриваться как в широком, так и в узком смысле. Основанием соответствующей дифференциации является юридическая техника законодателя.

С одной стороны, буквальное толкование ч. 1 ст. 46 Федерального закона «О биомедицинских клеточных продуктах» ${ }^{6}$ позволяет говорить о лицензионном режиме только производства биомедицинских клеточных продуктов, рассматривая государственный контроль за деятель-

4 Постановление Правительства РФ от 03.10.2018 № 1184 «Об утверждении Положения о лицензировании деятельности по производству биомедицинских клеточных продуктов» // СЗ РФ. 2018. № 41. Ст. 6272.

5 Приказ Минздрава России от 08.08.2018 № 512н «Об утверждении Правил надлежащей практики по работе с биомедицинскими клеточными продуктами» // Официальный интернет-портал правовой информации.URL: http://www.pravo.gov.ru. 31.10.2018.

6 Федеральный закон от 23.06.2016 № 180-Ф3 «О биомедицинских клеточных продуктах» // СЗ РФ. 2016. № 26 (ч. І). Ст. 3849. 
ностью в сфере обращения биомедицинских клеточных продуктов и выборочный контроль качества биомедицинских клеточных продуктов как отдельные правоотношения, направленные на обеспечение биобезопасности в сфере оборота биомедицинских клеточных продуктов, но не использующие для этого административно-правовые процедуры лицензирования соответствующей деятельности.

С другой стороны, нормативно обосновано существование широкого подхода к трактовке лицензионного режима, позволяющего охватить рассматриваемым понятием три направления государственного контроля в сфере обращения биомедицинских клеточных продуктов, реализуемого Росздравнадзором в целях обеспечения биобезопасности:

1) лицензионный контроль в сфере производства биомедицинских клеточных продуктов;

2) государственный контроль за деятельностью в сфере обращения биомедицинских клеточных продуктов;

3) выборочный контроль качества биомедицинских клеточных продуктов.

Интересен опыт зарубежных стран в части обеспечения биобезопасности при производстве и обращении биомедицинских клеточных продуктов. В первую очередь целесообразно указать на определенную разницу в понятийном аппарате, используемом отечественным и зарубежным законодателем. Так, руководства Евросоюза используют в отношении биомедицинских клеточных продуктов термин «передовые терапевтические медицинские продукты » (advanced therapeutic medicinal products ATMP), которые включают в себя три категории продуктов:
- терапевтические, созданные на основе соматических клеток;

- генные терапевтические;

- продукты тканевой инженерии.

Основополагающим нормативно-правовым документом, регулирующим оборот АТМР, является постановление Европейской комиссии (Regulations EC) № 1394/2007, выпущенное 30 декабря 2008 г. ${ }^{7}$ В 2017 г. был разработан стандарт GMP в отношении ATMP8.

В Канаде основные полномочия по лицензированию производства и обращения биомедицинских клеточных продуктов в соответствии c F\&DR и $\mathrm{MDR}^{9}$ возложены на Управление терапевтических продуктов бюро медицинских изделий Министерства здравоохранения Канады. В соответствии с подразд. 25(1) Правил диагностические устройства in vitro, которые используются учреждением для тестирования доноров на наличие трансмиссивных заболеваний или возбудителей заболеваний, должны быть лицензированы в Канаде, если тестирование проводится в Канаде. Если тестирование проводится за пределами Канады, диагностические устройства in vitro должны быть лицензированы либо в Канаде, либо в Соединенных Штатах. Исключение сделано в подразд. 25(2) для лимфогематопоэтических клеток, которые импортируются в Канаду для трансплантации конкретному реципиенту, где диагностические устройства in vitro, используемые при тестировании доноров, могут быть лицензированы в Канаде или любой другой юрисдикции.

Отдельно следует отметить, что в Канаде ведется список активных лицензий на медицинские устройства (MDALL) - это база данных, содержащая все лицензированные медицин-

7 Regulation (EC) № 1394/2007 of the European Parliament and of the council of 13 November 2007 on advanced therapy medicinal products and amending Directive 2001/83/EC and Regulation (EC) No 726/2004 (Text with EEA relevance) // URL: http://eurlex.europa.eu/LexUriServ/LexUriServ.do?uri=OJ:L:2007:324:0121:0137:en:PDF.

8 International experience in the regulation of circulation of biomedical cell products (BMCP) // URL: https:// beawire.com/ru/biomedical-cell-products/international-experience-in-the-regulation-of-circulation-ofbiomedical-cell-products-bmcp/.

9 Guidance Document for Cell, Tissue and Organ Establishments - Safety of Human Cells, Tissues and Organs for Transplantation // URL: https://www.canada.ca/en/health-canada/services/drugs-health-products/biologicsradiopharmaceuticals-genetic-therapies/regulatory-initiatives/cells-tissues-organs/guidance-document-safetyhuman-cells-tissues-organs-transplantation/document.html\#a2.4. 
ские устройства классов II, III и IV для продажи в Канаде, которые можно найти на веб-сайте Health Canada.

В США обеспечение биобезопасности в сфере оборота биомедицинских клеточных продуктов организовано путем осуществления последовательного контроля по нескольким направлениям: регистрация учреждения в качестве производителя биомедицинских клеточных продуктов; контроль обращения биомедицинских клеточных продуктов, который включает в том числе четко регламентированный порядок импорта биомедицинских клеточных продуктов (то есть деятельность иностранных агентов в сфере оборота БМК); контроль качества БМК; контроль и профилактика заболеваний

Так, Управление по контролю качества пищевых продуктов и медикаментов (FDA) отвечает за оценку безопасности, качества и эффективности клеток, тканей человека, а также клеточных и тканеобразующих продуктов - НСТ/ Ps, предназначенных для медицинских целей ${ }^{10}$.

Соответствующий контроль, во-первых, обеспечивается путем проведения регистрационных мероприятий среди субъектов, производящих биомедицинские клеточные продукты ${ }^{11}$. В течение 5 дней со дня начала операций по производству биомедицинских клеточных продуктов необходимо зарегистрировать и представить список всех таких продуктов, производимых предприятием, а также ежегодно обновлять свою регистрацию в качестве учреждения, участвующего в производстве и обороте биомедицинских клеточных продуктов.

Важно отметить, что регистрация и обновление данных осуществляются в электронном виде путем использования специализированного сервиса (по адресу: http://www.fda.gov/cber/ tissue/tisreg.htm).
В случае изменения владельца или местоположения учреждения, а также в случае изменения имени, адреса, номера телефона или адреса электронной почты агента США необходимо представить поправку к регистрации в течение 30 календарных дней с момента изменения.

Управление по контролю качества пищевых продуктов и медикаментов присваивает каждому месту производства биомедицинских клеточных продуктов постоянный регистрационный номер. Техническое принятие Управлением формы регистрации предприятия и перечня биомедицинских клеточных продуктов не означает, что предприятие соответствует применимым правилам и положениям в сфере обращения биомедицинских клеточных продуктов или что перечень биомедицинских клеточных продуктов прошел лицензирование ${ }^{12}$.

Государственный контроль за обращением БМК в первую очередь сосредоточен в сфере импорта БМК в Соединенные Штаты и регулируется таможенными законами и правилами, которые находятся в ве́дении таможенной и пограничной охраны США (СВР).

Обращение биологических и родственных продуктов, включая кровь и продукты крови, вакцины, аллергены, ткани, и клеточную и генную терапию регулирует Центр оценки и исследований в области биологии (CBER). CBER также регулирует оборот медицинских устройств, участвующих в сборе, обработке, тестировании, производстве и администрировании лицензированной крови, компонентов крови и клеточных продуктов. Иностранные фирмы, которые производят и импортируют в США продукты, регулируемые CBER, должны соблюдать обязательные требования FDA по обращению БМК до, во время и после импорта в Соединенные Штаты.

10 FDA Regulation of Human Cells, Tissues, and Cellular and Tissue-Based Products (HCT/Ps) Product List // URL: https://www.fda.gov/BiologicsBloodVaccines/TissueTissueProducts/RegulationofTissues/ucm 150485. htm.

11 Federal and State Requirements for HCT/Ps: An Overview // URL: https://www.mddionline.com/federal-andstate-requirements-hctps-overview.

12 CFR - Code of Federal Regulations. Title 21 // URL: https://www.accessdata.fda.gov/scripts/cdrh/cfdocs/cfcfr/ CFRSearch.cfm?fr=1271.400. 
Правила FDA (§ 1271.420 гл. 21 CFR) устанавливают основные стандарты и процедуры импорта БМК. Таким образом, Центр оценки и исследований в области биологии (CBER) и Управление по контролю качества пищевых продуктов и медикаментов (FDA) координируют свои усилия по обеспечению биобезопасности в сфере импорта биомедицинских клеточных продуктов ${ }^{13}$.

Функция контроля и профилактики заболеваний в сфере обращения БМК в основном возложена на центры по контролю и профилактике заболеваний (CDC), Министерство сельского хозяйства США (USDA), службу ветеринарного надзора за животными и растениями (APHIS) и таможенную и пограничную охрану США. Если в рамках профилактических мероприятий соответствующих служб выявляется подозрение, что БМК содержат этиологические вещества или не были протестированы на этиологические вещества, может потребоваться специальное разрешение на импорт этиологических веществ CDC.

Министерство сельского хозяйства США, Служба ветеринарного надзора за животными и растениями, ветеринарные службы регулируют импорт всех материалов животного происхождения, которые могут представлять опасность заболевания для скота США, а также импорт и транспортировку инфекционных организмов и переносчиков возбудителей болезней. Сюда относятся не только продукты животного происхождения и субпродукты, но и биологические материалы, которые содержат или контактировали с определенными организмами и материалами животного происхождения (включая культуры клеток) $)^{14}$.

Транспортировка человеческих тканей и клеток к месту производства должна контролиро- ваться по письменному соглашению между ответственными сторонами. Производственные площадки должны иметь документальное подтверждение соблюдения установленных условий хранения и транспортировки. Между ответственными сторонами должно быть заключено техническое соглашение, которое определяет обязанности каждой стороны по обеспечению биобезопасности в процессе обращения биомедицинских клеточных продуктов ${ }^{15}$.

Контроль качества биомедицинских клеточных продуктов осуществляется следующими способами. Законодательством США предъявляются требования к отбору доноров, производству, контролю качества, упаковке, маркировке, дистрибуции, хранению и применению клеточных продуктов и направлены на предотвращение возникновения инфекционных заболеваний у реципиентов. Программа по обеспечению качества включает валидацию, мониторинг отклонений по качеству, квалификацию персонала, корректирующие и предупреждающие действия, незамедлительное информирование касательно риска инфекционных заболеваний, четкое документирование всех процессов и аудиты.

Анализируя требования к качественным характеристикам биомедицинских клеточных продуктов в США, целесообразно отметить, что особенности правового статуса биомедицинских клеточных продуктов приравнивают их к лекарственным средствам (реже к медицинским изделиям) или к материалам для трансплантации с определенными особенностями, обусловленными их природой. Таким образом, биомедицинские клеточные продукты как самостоятельный объект правового регулирования в США отсутствует ${ }^{16}$.

13 Importing CBER-Regulated Products into the United States // URL: https://www.fda.gov/vaccines-bloodbiologics/exporting-cber-regulated-products/importing-cber-regulated-products-united-states.

14 Importing CBER-Regulated Products: Clinical Laboratories and Basic Scientific Research // URL: https://www.fda. gov/vaccines-blood-biologics/exporting-cber-regulated-products/importing-cber-regulated-products-clinicallaboratories-and-basic-scientific-research.

15 Manufacturing Cellular Products for International Clinical Trials // URL: https://docplayer.net/18178294Manufacturing-cellular-products-for-international-clinical-trials.html.

16 Шабров Р. В., Шадрин А. Д., Минюк Н. С. Обращение биомедицинских клеточных продуктов: анализ проблем правового регулирования // Ремедиум. 2016. № 9. 
Если биомедицинские клеточные продукты подпадают под действие норм законов о лекарственных средствах, то требования к качеству предъявляются в соответствии с Законом 351 PHS Act или Законом о продуктах питания, лекарствах и косметике ${ }^{17}$ и БМК рассматриваются как лекарственные средства или биологические продукты. В этом случае производство биомедицинских клеточных продуктов требует получения биологической лицензии и должно соответствовать требованиям действующих Правил надлежащей производственной практики (cGMP).

Биомедицинские клеточные продукты на основе стволовых клеток, одобренные FDA для использования в Соединенных Штатах, состоят из кроветворных стволовых клеток (кроветворных клеток-предшественников), полученных из пуповинной крови. Эти продукты стволовых клеток, одобренные FDA, перечислены на официальном сайте FDA.

Когда продукты стволовых клеток используются несанкционированным способом, FDA уполномочено принимать меры административного характера в зависимости от тяжести совершенного правонарушения ${ }^{18}$.

Контрактные лаборатории, выполняющие тестирование доноров биомедицинских клеточных продуктов, должны иметь соответствующую сертификацию CLIA и одобренные или разрешенные скрининговые тесты доноров в соответствии с инструкциями производителя. Такие лаборатории считаются учреждениями (§ 1271.3 (b)), они производят (§ 1271.3 (е)) биомедицинские клеточные материалы и обязаны зарегистрироваться в FDA (§ 1271.21) ${ }^{19}$.
Clinical Laboratory Improvement Amendments (CLIA) 1988 г. являются федеральными нормативными стандартами США, которые применяются ко всем клиническим лабораторным испытаниям, проводимым на людях в Соединенных Штатах, за исключением клинических испытаний новых лекарственных средств и фундаментальных исследований ${ }^{20}$.

Если вы являетесь учреждением, производящим биологические клеточные продукты, описанные в § 1271.10, независимо от того, заключен ли с вами контракт, вы обязуетесь разрешать FDA проверять любое место производства в любое разумное время и разумным образом для определения соответствия обязательным требованиям закона. Проверки могут проводиться по мере необходимости в соответствии с решением FDA и включать проверку объектов, оборудования, готовых и незаконченных материалов, контейнеров, процессов производства, непосредственно биологических клеточных продуктов, маркировки, записей, файлов, документов и средств контроля, необходимых для обеспечения биобезопасности в процессе производства БМК. Проверка может быть проведена как с предварительным уведомлением, так и без такового в обычные рабочие часы. Периодичность проведения контрольных мероприятий определяется по усмотрению FDA ${ }^{21}$.

1 июля 2005 г. вступили в силу стандарты (tissue standards) Объединенной комиссии по аккредитации организаций здравоохранения (JCAHO), обязывающие каждую организацию, аккредитованную ЈCAНО, доводить до сведения учреждения НСТ/Р, из которого была получена

17 Federal Food, Drug, and Cosmetic Act (FD\&C Act) // URL: https://www.fda.gov/regulatory-information/lawsenforced-fda/federal-food-drug-and-cosmetic-act-fdc-act.

18 FDA Warns About Stem Cell Therapies. Some patients may be vulnerable to stem cell treatments that are illegal and potentially harmful // URL: https://www.fda.gov/consumers/consumer-updates/fda-warns-about-stemcell-therapies.

19 Guidance for Industry Current Good Tissue Practice (CGTP) and Additional Requirements for Manufacturers of Human Cells, Tissues, and Cellular and Tissue-Based Products (HCT/Ps) // URL: https://www.fda.gov/ media/82724/download.

20 Clinical Laboratory Improvement Amendments // URL: https://en.wikipedia.org/wiki/Clinical_Laboratory_ Improvement_Amendments.

21 CFR - Code of Federal Regulations. Title 21 // URL: https://www.accessdata.fda.gov/scripts/cdrh/cfdocs/cfcfr/ CFRSearch.cfm?fr=1271.400. 
ткань, обо всех побочных реакциях, связанных с использованием тканей (включая передачу заболевания или другие осложнения) ${ }^{22}$.

Подводя итоги, целесообразно отметить, что отсутствие законодательного определения лицензионного режима производства и обращения биомедицинских клеточных продуктов, а также четко закрепленных особенностей специального лицензионного режима обращения биомедицинских клеточных продуктов (в том числе на территории инновационного центра «Сколко- во», территории международного медицинского кластера, территории опережающего социально-экономического развития и др.), отсутствие нормативно закрепленного комплекса профилактических мероприятий, направленных на минимизацию рисков распространения инфекционных заболеваний в результате применения БМК, создает предпосылки распространения угроз биологического характера на территории Российской Федерации, подрывая национальную безопасность государства в целом.

\section{БИБЛИОГРАФИЯ}

1. Мохов А. А. Правовой режим биомедицинских клеточных продуктов как объектов гражданских прав // Гражданское право. - 2017. - № 3. - С. 29-31.

2. Правовое регулирование экономической деятельности: единство и дифференциация / отв. ред. И. В. Ершова, А. А. Мохов. - М. : Норма: Инфра-М, 2017.

3. Шабров Р. В., Шадрин А. Д., Минюк Н. С. Обращение биомедицинских клеточных продуктов: анализ проблем правового регулирования // Ремедиум. - 2016. - № 9.

Материал поступил в редакцию 10 сентября 2019 г.

\section{REFERENCES (TRANSLITERATION)}

1. Moxov A. A. Pravovoj rezhim biomedicinskix kletochnyx produktov kak obektov grazhdanskix prav // Grazhdanskoe pravo. - 2017. - № 3. - S. 29-31.

2. Pravovoe regulirovanie ekonomicheskoj deyatelnosti: edinstvo i differenciaciya / otv. red. I. V. Ershova, A. A. Moxov. - M. : Norma: Infra-M, 2017.

3. Shabrov R. V., Shadrin A. D., Minyuk N. S. Obrashhenie biomedicinskix kletochnyx produktov: analiz problem pravovogo regulirovaniya // Remedium. - 2016. - № 9.

22 Human Cell \& Tissue Products (HCT/P) Adverse Reaction Reporting // URL: https://www.fda.gov/vaccinesblood-biologics/report-problem-center-biologics-evaluation-research/human-cell-tissue-products-hctp-adversereaction-reporting. 